\title{
Note on the text
}

The text is taken from Richmond Lattimore, trans., The Odyssey of Homer (New York: Harper, 1965), which has been chosen for its closeness to the original, and which is reprinted by permission of HarperCollins Publishers. All line references are to Lattimore's translation, and not the original Greek, though the two often coincide. Quotations from the Iliad are also from Lattimore's version (Chicago: University of Chicago Press, 1951). References to 'Graves' are to Robert Graves, The Greek Myths, 2 vols, 2nd edn (Harmondsworth: Penguin, $1960)$, and are to section rather than page number. 